\title{
Consumer credit default and collections: the shifting ontologies of market attachment
}

\author{
Joe Deville
}

Goldsmiths, University of London, London, UK

\begin{abstract}
Existing accounts of consumer credit market making have done much to explore the business models, technologies and advertising practices of lenders, and the financial circumstances of borrowers. However, the space of interface between consumer credit debtor and debt collector remains underexplored. Drawing on interviews with debtors and an exposition of debt collections technologies, the paper demonstrates how this market domain, in seeking to prompt calculative engagement, depends on its ability to intersect successfully with the everyday lives of economic agents. Critically engaging with key currents emerging out of the 'economization' programme it builds on its attention to the socio-material mechanisms of market making. However, the paper argues that materially sensitive economic sociologies need to account more thoroughly for the place of affect in markets. This is particularly relevant when studying consumer markets, where exchanges routinely centre on intimate and embodied encounters between economic actors.
\end{abstract}

Keywords: affect; consumer credit; consumption; debt collection; default; intimacy; markets

What was once a radical claim is now an oft-rehearsed observation: that social life can be followed as it is made and stabilised not only in the interactions between humans, but between a broad range of both human and non-human entities and processes. Recently, drawing on the intellectual and methodological heritage of Actor-Network Theory (ANT) (Latour 1987; Callon 1986a; 1986b), Koray Çalışkan and Michel Callon $(2009 ; 2010)$ have sought to formalise this re-specified empirical focus into a comprehensive research programme for the study of economic life: the study of processes of 'economization'. As is implied by the term, this work places an emphasis on the making of things (behaviours, organizations, institutions, objects (Çalışkan and Callon 2009, 370)) as 'economic'. In so doing, there is clear ambition to provide a bulwark against the domination, within economic sociology, of 'new' economic sociologies which can trace their lineage back to Mark Granovetter's (1985) seminal reinterpretation of Karl Polanyi's thesis, and account for the ways in which economic forms are variously 'embedded' within society. But, as Liz McFall 
(in press) writes, despite the rejuvenation of the sociology of markets spurred by such insights, and despite the extensive but often theoretically unrelated work within the sociology of consumption seeking to understand the drivers of consumer behaviour, 'there remains a thick, and quite understandable, haze around private consumer calculation'.

This paper responds to this challenge by focusing on the case of consumer credit default. This is, at once, an exposition of a particular component of consumer credit, and an expansion of the empirical terrain for the study of consumer credit. For until relatively recently, consumer credit is an analytical object that sociological writing has tended to use as a device through which to examine social and economic issues. This is in evidence in both early and later work centring on the relationship between (postmodern) consumerism and 'consumer society'. Here consumer credit is often breezed through, somewhat uncritically, as more or less directly and instrumentally linked to practices of consumption (a theme that echoes from Baudrillard (1998 [1970] to Bauman (2007)). The credit card is part of contemporary consumerism's indispensable fuel, and, as such, an analytical passage point that needs to be passed through, not dwelled on.

Other writers who have subjected consumer credit to a more sustained analysis nonetheless have tended to shy away from a detailed interrogation of either the material composition of consumer credit, or how users encounter it (see, notably Manning, 2000; Ritzer 1995; 2005). It is the 'larger social forces' (Manning 2000, 292), of which banks are held to play a significant and at times predatory role, that shape its emergence and use, as well as the social consequences that result (Montgomerie 2007, 162-163; see also: Klein 1999; Shaoul 1997). 
But, as Martha Poon (2007; 2009) shows (see also: Leyshon \& Thrift 1999), there is real value in attending to consumer credit not just as a social outcome or problem, but as a composition of diverse socio-material technologies. In her account, materiality matters: the credit score, via its movement from consumer credit to secured credit lending, is shown to have played a key causative role in the global economic downturn, perhaps even trumping the (in)actions of the potentially 'irrational, fraudulent, or extragovernmental' human actors that surround it $(2009,672)$. Poon thus points towards the value of a materially sensitive empirics of consumer credit's calculative apparatus, although her empirical focus remains distant from the intersections between consumer credit and the everyday lives of its users. Somewhat closer is Paul Langley's (2008a) materially attuned exploration of the everyday life of borrowing (see also: Marron (2009)). For Langley, consumer credit is read as a potent actualisation of the apparent so-called 'democratization of finance' and the 'financialization' of social life. (This is a term whose heritage has been extensively summarised (Engelen 2008; French, Leyshon, and Wainwright 2011; Montgomerie 2008). For present purposes, it is enough to characterise it as engaging with the problematic of the increasing centrality of the global flows of finance to the lives of market actors in a range of settings).

Yet despite the ways in which this assembly of academic endeavour has opened up consumer credit as a rich object of enquiry (see also: Montgomerie 2006; 2007; T. A. Wainwright 2009; 2011), there is still significant work to be done. This is partly because of the dearth of sociological work on the debtor-collector interface (although Dawn Burton's (2008) book addresses this in part). But also, further effort is needed to meet the vital challenge set by Langley: that is, 'how, precisely, these tendencies to financialization materialize' (Langley 2008b, 134; emphasis added). For, despite - in 
the wake of Randy Martin's (2002) book on the subject - daily or 'everyday' life being frequently referenced as key to understanding financialisation, what this ontological category is composed of, and what role it plays not only in relation to consumer credit, but the way people engage with a whole range of financial products, remains insufficiently researched. I therefore suggest a redirection of attention: towards the way certain markets depend on, reshape, and operate through processes that might variously be understood as private, intimate and/or 'affective'.

In setting out this new direction for the study of financial consumption, and illustrating its implications through research into defaulting debtors and the debt collections industry (an industry in which I include creditors' own internal collections operations), the paper will move through three parts. The first outlines key existing conceptual and empirical deficits, arguing that recent research in economic sociology has tended to neglect the realm of human materiality - those that stem from and become entwined with emergent, corporeal processes — as a key site for the conduct of market processes. Important here is to make clear how the turn to affect, with its Deleuzian philosophical heritage, should not mark a retreat from empiricism, but its strengthening. The second part opens up the object of study at the centre of this paper, arguing that it is important to account for consumption as a distributed activity characterised by struggles over 'market attachment'. These two parts lay out the ground for the empirical analysis in the third part. By providing an exposition of some core debt collection technologies and how they seek to shape the everyday lives of debtors, briefly introduced by insights from interviews with defaulting debtors in the UK, the paper seeks to demonstrate the centrality of the management of affect in the relations that inhere between debtor and collector. This paper is based on research conducted between 2008 and 2012, including 20 interviews with heavily indebted and 
defaulting debtors, observations in collections agencies, interviews with collections professionals, and an analysis of online debtor forums and a range of documentary evidence and collections conference presentations. All relevant individual and company names have been changed.

\section{The intimate and the affective in markets}

The exclusion of the intimate and the personal from consideration as a valid domain for the study of market processes from the perspective of economic sociology has been documented in some detail by Viviana Zelizer (2001; 2002a; 2002b), in particular in relation to what she refers to as oscillations between 'hostile worlds' and 'nothing but' theses. The former and most longstanding sees the insertion of market relations into personal worlds as corrosive. Simultaneously, the insertion of personal relationships into economic realms is seen as disruptive, with the potential to induce 'inefficiency, favouritism, cronyism and other forms of corruption' (Zelizer 2002a, 276). For Zelizer, the latter — the 'nothing but' thesis — incorporates those approaches that bring the personal and the economic together under one transcendent principle. She points to explanatory frameworks that argue that social processes of all kinds are seen as 'nothing but' an expression of underlying forms of economic rationality.

In the rise of so-called 'new' economic sociology, Zelizer sees some ways out of this opposition, by 'treating economic processes and behavioural assumptions $[\ldots]$ as products of underlying social processes' (Zelizer 2001, 44). Given the recent challenges from the economization programme, this particular aspect of Zelizer's argument falls victim to the terms of its own analysis. Seeing economic processes as ultimately social can be seen as a variant of a 'nothing but' argument, in which economic processes come to be understood as 'nothing but' social ones (Çalışkan and Callon 2009, 281)). Yet Zelizer's case is more nuanced: for even within new 
economic sociology, Zelizer traces the perpetuation of a 'hostile worlds' thesis, in particular in their choice of empirical objects. As she argues, '[t]he field repeatedly focuses on firms and corporations - allegedly "true markets"-while relegating other forms of economic activity (such as gift transfers, informal economies, households, and consumption) to a nonmarket world' $(2001,44)$. In regard to this partial engagement of the economic, I would suggest that the research programme outlined by Çalışkan and Callon is as complicit as any other. With some exceptions, works drawing on the intellectual architecture of ANT in the analysis of economic processes, have similarly headed straight to those sites that appear to represent instances of 'true' markets. This includes a focus on trading rooms and the world of high finance (e.g. Beunza \& Garud 2007; Beunza \& Stark 2004; Hardie \& MacKenzie 2007; Lenglet 2011; Lépinay 2011; MacKenzie 2006; 2009; Millo 2007; Muniesa 2008), but also includes an attention to organizational behaviour more generally (e.g. Callon 2002; Cooren 2004; Cooren, Brummans and Charrieras 2008; Stark 2009), as well as the development and formatting of (credit) risk management technologies (e.g MacKenzine 2006; Poon 2007, 2009). This is not a critique of these studies in their own right. However, I echo similar conclusions by Langley (2008a, 7) and Franck Cochoy $(2008,15-16)$, in arguing that the choice of subject matter of the economization programme reveals a field less than comfortable with some of the more intimate, everyday spaces of socio-economic life (Langley) including, notably, spaces of consumption (Cochoy).

The apparent hesitations around studying intimate socio-economic relations within this work also mean that there is a tendency to omit discussions of the role of the corporeal within market processes (an important exception is Mackenzie (2009)). Work clustering around the economization approach has otherwise been highly 
successful in demonstrating the value of attending to the socio-material distribution of agency in markets. However, the lack of attention to what Mcfall refers to as 'corporeal materialities' $(2009,53)$ as themselves means through which markets operate is striking when considered in the light of the extensive work that has gone into understanding the multiple and contested compositions of people, technologies, and bodies in work stemming from Science and Technology Studies (STS) more generally (Gomart and Hennion 1999; Haraway 1997; Hennion 2007; Latour 2004; Michael 2006; Mol 2002; 2008).

I would therefore like to suggest that STS informed economic sociology take seriously the status of corporeal action to the making of markets as a site of processual interrelatedness. One way to do so, I propose, is to also take seriously the intersection between socio-material processes and the generation and management of 'affect', a core component of Deleuzian philosophy (see: Deleuze and Guattari 1988). For many other writers interested in the messy, intimate, in-between relationships between bodies and worlds, this has been a core analytical category. As Gregory Seigworth and Melissa Gregg write, '[a]ffect is found in those intensities that pass body to body [...], in those resonances that circulate about, between, and sometimes stick to bodies and worlds, and in the very passages or variations between these intensities and resonances themselves' $(2010,1)$.

Yet in making the case for the relevance of considering the role of affect in markets, it has to be recognised that, as Lawrence Grossberg argues, affect 'has come to serve, now, too often as a "magical” term' $(2010,314)$. He continues, 'there is a lot of theorizing that does not do the harder work of specifying the modalities and apparatuses of affect, or distinguishing affect from other sorts of non-semantic 
effects' (ibid; see also: Probyn 2010, 74). In other words, identifying the existence and production of affect, or naming things as affective, is not, in itself, 'good enough'.

I suggest, therefore, that in seeking to follow such emergent, social and material coming-togethers, there is thus room to bring some of ANT's empiricism to the study of affect. There is nothing in the analysis of affect that is contrary to approaches that seek to 'follow an object', wheresoever it may lead. The methodological challenge is instead to undertake a study of those entities which emerge in moments and space of inter-relatedness, what Patricia Clough calls an 'empiricism of sensation, not an empiricism of the senses, not the sense knowledge underpinning methodological positivism, but an empiricism of the 'in-experience'' (2009, 51; see also: Hennion 2007; Gomart and Hennion 1999).

There exists a growing body of work exploring such processes within markets, although this often tends to be limited to debates surrounding the production and measurement of value in light of the apparent rise of affective and immaterial labour (see: Arvidsson 2005; Clough et al 2007; Dowling et al 2007; Dowling 2012; Lazzarato 1996; Negri 1999; Zwick et al 2008). Exceptions to this include Celia Lury and Nigel Thrift, who both draw on concepts of affect in order to explore how affective processes can become the subject of highly strategic socio-materially derived practices of management and capture (Lury 2004; 2009; Thrift 2005; 2007). Franck Cochoy, meanwhile has called for a more concerted study of both material 'devices' and human 'dispositions', turning attention to how markets can become oriented towards a range of embodied human states, ranging from habit, to curiosity, to weariness, to temptation (Cochoy 2007; 2011). Understanding the role of such processes, is thus, I propose, absolutely central to understanding many forms of market and, in particular, consumer markets. As McFall argues, consumption has at 
its heart, what she calls, drawing on William James, 'the mess, or dirt, of private fact', in the need to 'reach into the private thoughts, needs and longings of individuals' (McFall forthcoming in press). That is to say, stimulating consumer engagement depends on the way in which the intimate and the personal co-emerge with consumer markets.

However, in the case of the present object - consumer credit default - this means opening up the interface between not only markets and affect, but also consumption and markets. This is to understand the way in which forms of credit transform consumption into a (temporally and spatially) distributed process.

\section{Distributed consumption: the case of consumer credit default}

Keeping debt 'revolving' is fundamental to the global expansion of consumer credit debt (Langley 2008a, 188-193; 2008b; Montgomerie 2006; 2007; 2009). However, discussions on the subject tend to occur in isolation from work on understanding the relationship between financial products and consumption. Franck Cochoy (2012; see also Araujo, Kjellberg, and Spencer 2008; Deville 2012b) argues that products are not stable, cohesive things but, in the language of economist Kevin Lancaster, 'bundles' (see also: Barr-Gill: 2006). While more conventional monetary transactions bundle together relations around a single moment of exchange, forms of consumer credit extend this moment out, affording — whether the user wants it or not—a multiplicity of potential connections to the future. These connections - including the future actions of borrowers themselves - are an intimate part of the variably enacted bundle (or, to bring this closer to the language of recent debates within economic sociology, 'assemblage' or 'agencement' (see: Callon 2005; Lury 2009; McFall 2009) that is consumer credit. This includes the rate of interest being charged to an individual borrower, which (at a simple level) is in part the result of calculations aiming to 
preempt the consequences of potential future actions by the full range of borrowers associated with that product.

Consumption, in the case of consumer credit, is therefore a distributed process, involving multiple moments and places where the notional 'consumer' (sometimes borrower, sometimes defaulter) is approached or encouraged to in some way manage his or her debts. Analogous consumer-object relations have been explored within work looking at the increasing centrality of relationship building within marketing practice (see: Zwick, Bonsu, and Darmody 2008)), including the widening applications for Customer Relationship Management (CRM) and database driven marketing techniques (see: Arvidsson 2002; Beckett 2011; Danna 2002; Gandy 1993; Knox et al. 2010; Lyon 2001; Zwick and Denegri Knott 2009). This work has tended to focus on largely critical explorations of what these techniques stand for, whether that is as a new form of discriminatory politics or the consumer as a new source of value (a notable exception is Knox et al 2010). Closer to the concerns of this paper is work that traces the specific modalities through which consumption occurs as a potentially post-purchase activity (see: Shove and Araujo (2010)), or that which explores the dynamic, often ambivalent mutually constitutive 'bindings' that can characterise user's engagements with specifically financial objects (see: Zwick and Dholakia 2006; Cook, Smith and Searle 2009). Here it is important to recognise that financial products embody a particular distribution of agency, for, in their very dependence on - and exploitation of - economic uncertainty, they always retain the ability to 'bite back' in unexpected and potentially undesirable ways (Cook et al. $2009,150)$.

As we will see, it is particularly strong forms of consumer-product 'binding', reinforced by relations of potentially legally enforceable obligation, that are at the 
heart of the debtor-collector relationship. But does the apparent distance between a 'moment' of consumption and the consumer's interaction with the collector mean that these debtors are no longer consumers, or that such processes should not be described under the sign of consumption? Perhaps not. First, as noted, all forms of consumer credit can be seen as retaining the potential to distribute consumption over time. The experience of defaulting on a debt can therefore be seen as one component in a diverse spectrum of potential market encounters with consumer credit. Second, even if, as will become clear, defaulting debtors do not see themselves in any simple sense as 'customers' of the consumer credit industry, the technologies to which they are subject are resolutely grounded in contemporary consumer marketing technologies and expertise. And, third, it is noteworthy that the ambivalences surrounding this question have not gone unnoticed within the contemporary collections industry. Garry Stran, the chief executive of Clarity Credit Management, a leading UK collections agency addresses this directly:

Here at Clarity we, just like almost all other customer service organisations, place a lot of emphasis on the quality of the conversation that takes place between our people and the customer. In our case the term 'customer' is slightly misleading as ordinarily the people we are talking to are debtors who, for whatever reason, have not met the terms of the contract that they entered into. (Stran 2008, 29; emphasis added)

Are debtors customers or not? Stran seems unsure. As he notes, their relationship to the collector seems to be defined by their past actions: when they were borrowing and meeting the terms of their contract then they were customers; now, however, what they really are, are defaulting (contract breaking) debtors. This debate was continued in the industry's latest revision of its 'Code of Practice', with discussions centering on whether to name the targets of collections activity as debtors or customers. In this case, a decision was made to stick with the former, the stated justification being that it matched the language of the regulator (Credit Services Association 2012a; 2012b) 
Perhaps calling defaulters 'customers' rather than 'debtors' is simply more pleasant, or perhaps it speaks to a certain business ethics? This is undoubtedly part of what is going on here. Yet there is more to it than that. I suggest that the tensions in naming debtors point towards the central problematic of the creditor that has to deal with the defaulting debtor: the very weakness of some of the ties binding defaulters to their products (when viewed from the perspective of the creditor). For debt collection is a competitive business, with defaulting debtors typically owing multiple creditors simultaneously, in the UK often over half a dozen. Despite the fact that obligation is at the heart of processes of debt collection, this is a market that therefore remains one characterised by struggles of market attachment (Callon, 1998; Callon et al., 2002; Callon \& Muniesa, 2005; McFall, 2009b; Muniesa et al., 2007; Muniesa, 2009a). Put simply, thinking of markets in terms of movements of attachment—and detachment-draws attention to how the socio-material assembly of calculative spaces, via 'market devices' involves multiple and ongoing processes of association and dissociation between market actors. It is the calibration of these devices and, I would argue, corporeal encounters, that 'affect the ways in which persons and things are translated into calculative and calculable beings' (Muniesa et al., 2007: 5).

In this context, the struggle between creditors holding defaulting debts plays out not in the attempt to enrol customers, but to convince already enrolled debtors to pay you over others, for as small an outlay as possible (see: Deville (2012a)). However, the challenge for the collector is not to attach borrowers to their credit products, as legally they already are, bound by their credit agreement. Instead, the challenge is to reattach value to the product. That is, to make the credit product 'matter' to the debtor in such a way that they perceive/feel that the transfer of value from them to the creditor is a necessary part of their relationship with their debt. 
From the perspective of the debt collection industry, including both creditors undertaking their own collections work and external collections companies, the debtor can therefore, be seen as a variably enacted market assemblage: there are parts of their business in which their connection to the debtor can feel more like a more conventional customer-producer relationship. Here, the aim is to keep debtors happy, to make sure that they pay you, not others. But, there are also parts of their business where translating the debtor into revenue happens at the site of the obligation which the debtor has to repay. From the point of view of the collections industry, therefore, the debtor is hybrid: they are attached to you both as a customer and because of an (legal) obligation; they are a 'debtor-customer'.

Yet in attempting to meet the challenge posed to them by this hybrid entity, collectors are presented by a further problematic: the emptiness of many of their threats. For, despite frequent threats to the contrary, given the expense, creditors, or the collectors working on their behalf, will often avoid litigation for as long as they can, especially if the outstanding balance is low (see: Centre Management Research Centre [CMRC] 2008, 109). These constraints led one industry solicitor to begin an article by repeating a sentiment he claims is commonplace in the industry; that it is 'a debtor's world', concluding that the debtor has been 'elevated into a very advantageous position' (Kirton 2010, 25). A tactless exaggeration maybe, but it points towards a frustration emerging from an industry whose key revenue source does not feel secure in its grasp.

\section{Market encounters between defaulters and collectors}

Whereas for the occasional defaulter a simple automatically generated letter may be enough of a disciplinary prompt to encourage them into returning to an 'acceptable' pattern of repayment behaviour, the more serious debtor can expect to face a 
persistent barrage of reminders, threats and solicitations to enter the house, either as a mid-morning interruption through the letter box or to be discovered upon returning home from work. It is typical for this material paraphernalia of credit default collections letters, statements, reminders - to accumulate in the home, with many of those that I met either pointing to piles of partially opened post, or indicating folders, drawers, or boxes where this collections ephemera would gather, potentially mixed in with bills as well as sometimes letters from debt advice services.

This physical barrage is inevitably supplemented by the quite different intrusive rhythm of the telephone call. Although collection organisations are prevented from 'harassing' debtors with excessive attempts to contact them (see OFT 2012), given the fact that it is common for many defaulting debtors to have multiple debts, the combination of many collectors each trying to contact the debtor means that defaulting debtors will often experience a high volume of calls throughout the day, even if each collector only calls once. This led many of the debtors I spoke with either to look to minor technological counterstrikes-employing the caller ID function on their phones to screen out at least some of the calls—or to unplug the phone altogether.

Attempts at generating repayment thus encounter a domestic landscape where the spectre of debt is likely already materially present, even if reminders are being inserted by competitors. In addition to this are the range of ideas, worries, preconceptions, in part perhaps shaped by fragments of information received from diverse sources, some correct, some less so, about the consequences of default and the sanctions likely to be used by a collector.

This complex and varied domestic territory is the empirical space which the collector has made their speciality. Given its likely partial pre-formatting through 
attempts at contact by other collections organisations or a creditor that worked a specific account previously, this space is one in which attachments between debtor and potentially numerous debts already exist - even if some of these attachments are, from the creditor's point of view, perilously close to rupture. On the one hand, this is a challenge for the new entrant into the home looking to grab a debtor's attention. On the other, for a collector able to do so, such connections are a market opportunity: before each attempt at contact, there already exist connections which they can exploit if only they can solidify and individualise them, by generating moments of calculative attention focused on them.

An illustration of how a diffuse, embodied sense of worry has the potential to coalesce into a moment of attention is provided by Eve, who, at the time we spoke in 2009, was living in a council flat in North London with her three young girls and was now to a large extent, dependent on welfare support. She had built up large debts, having used credit cards at least in part to pay for her day to day expenses and to supplement the income she received from low paid irregular work, or to tide her over in periods of unemployment. She describes a typical entry of a collections letter into the home:

[A]s soon as it comes I have to open it...at least it's for me to know what is there in [sic], I start preparing my mind or whatever towards it. The first thing, as soon as I open the door [and] I see any letter, the first thing, before I even take off my coat anytime [sic], I just open the letter and see what it's all about. If it's one I have to panic [about], I start panicking. If it's one I just have to put away... If it's one I have to make a phone call, immediately I just make a phone call. [emphasis added]

Taking this extract at face value, Eve describes a complex intersection of body and calculation. In Eve's account, she describes beginning by 'preparing' her mind towards the letter, to get her combined mind/body in a necessary state of calculative and emotional readiness for her to be able to deal with whatever actions she feels the letter demands. The most mundane, least problematic outcome is if the letter is purely 
informational; if so, it is read, then put away. But Eve describes two further potential outcomes, if the letter is understood as demanding an immediate response: the first is panic, the second is a cognitive engagement. The collections letter invites an affective response, which then becomes respectively stabilised as emotion and calculation. This does not necessarily have to be a quantitative assessment, for, as Cochoy argues, calculation routinely involves both quantitative and qualitative assessments - what he calls processes of 'qualculation' (Cochoy 2002). Here, this might include the calculative processes that surround and stem from putting the letter away or making a phone call.

Panic is a particularly potent mode of bodily response for the collector in its coemergence with calculation. Panic and clearly defined calculative action, body and mind, need, according to Eve's account, to become separate and distinct entities. However, crucially, this is not as a result of the precise contents of the particular letter in hand, but in anticipation (and I draw here on Adams et al. (2009)) of a yet to be unveiled future, with both states briefly coexisting in a state of unrealised existence, each ready to become fully realised as required once the letter is opened. On the one hand, here we apparently see the socio-material construction of calculation as variously described by the economization programme: a debtor's cognitive capacities are variously equipped and translated through the socio-material device of the collections letter. But what such accounts miss out on, is that the moment that Eve picks up this letter is the moment at which, from the point of view of the collector, affect has been successfully 'captured' (Massumi 2002). An emergent, affective state of anxious anticipation, generated by the predictable uncertainty of being subject to the repeated insertion of technologies of debt collection into Eve's life, are-in and 
through an equally emergent letter-grasped in a process of unfolding abstraction and stabilisation.

However, as outlined earlier, if we are to bring a study of affect into the study of the composition of markets, it is not enough simply to simply identify relations as affective and leave it there. Instead, I want to follow the production, of affect, of which Eve's case provides such a vivid illustration, to its source. Here, I argue, things begin to become more complex. For the success of collections does not just stem from the simple generation of fear and threat: although these undeniably play a critical role (and on which see Massumi (2005)) they do so only as part of a process of affect management.

Evidence of this can be found in the content of collections conversations. Having listened in on dozens of collections conversations, both sitting next to collectors and via recordings, in three of the largest collections agencies in the UK, it is fairly straightforward to find moments in the conversation designed to stimulate discomfort, anxiety, panic, and so forth. Take the following recorded conversation I listened to at Gamma, a major UK debt collections agency. The conversation is between Tom the collections agent, whose tone is always polite and understanding, and Sarah, a debtor from a major northern UK city, owing a total of around $£ 3000$ to the client, a major UK retail bank. At the time of the call she was dealing with her young children who could be heard in the background. She was unemployed, but hoped to be able to find work once her son started school later that year. In the meantime she was claiming a variety of state benefits. Her partner was a taxi driver; as Sarah put it, “it's no guaranteed wage, so we just pay what we can, where we can. We're just trying to get everything sorted out at the moment". The extract starts once the agent has established as much as he can about the debtor's situation. Importantly he has established that 
there is an asset (a property) that he will try to use as leverage over the course of the conversation. This section of the call begins with a veiled (veiled in part to ensure regulatory compliance) threat, combined with a suggestion for how Sarah might respond:

Tom: Now, if you want to avoid any further action against yourself, or obviously against your property, or anything along those lines, all I could suggest, is that you speak to your friends and family, and see if you're able to raise the funds to close this off.

Sarah acknowledges the threat, but suggests she is unable to respond as Tom wants:

Sarah: Right, I don't think.... I can't see that being able to be possible, to be honest.

On the basis of this, Tom first offers understanding ("I understand. It's a lot of money"), then respite ("What I'm going to do, I'm going to put the account on hold for 2 days for you"), then some degree of flexibility ("I'm not expecting you to come back to me in 2 days time and say, ok, here’s almost $£ 3000$, [but] I would expect you to know whether you're in a position to get those funds together"). Then, finally, this package is wrapped up with a more extensive outlining of the specific content of the threat that is in play - which, to be precise, is that the bank might try to connect this unsecured loan to the debtor's secured asset: her property (in fact, there are many processes that would need to be undergone first, including being taken to court; for such a relatively small balance, this is perhaps unlikely). ${ }^{\text {ii }}$

Tom: Now, at that point, I'll have to build up the pre-sue report. I'll have to put down that you own the property, your husband been a self employed taxi driver, all this, I need to put this down and pass this to litigation dept. As I said, they're not going to be worried about the money. They can see that you've got a tangible asset, it's something that, possibly not in the short term, but in the medium term, or possibly in the long term, they're going to get the money back, plus any charges, plus any court costs.

This conversation provides a good summary of the structure of many collections conversations, in which adverse consequences and possible remedies, veiled threat and apparent empathy are tossed together - a process of affective management which 
continues as this particular conversation progresses, ending with the agent 'closing' the call:

Sarah: Is there no possible way that I can pay it off equally per month

Tom: There won't be. Basically, our remit is to give you the opportunity to repay the full balance. If you're not able to do that, we'll pass it onto our litigation dept, and they'll decide on the best course of action.

Sarah: Right, ok

Tom: I'll leave it with you. Obviously, come back to me before $5 \mathrm{pm}$ on Wednesday.

It is common for each collections organisation to have their own guideline scripts for sales agents to follow (the better operations monitor conversations for both regulatory compliance and collections technique by listening to, and potentially scoring, random recorded calls). This is part of each organisation's unique 'secret sauce' for collections - a result of trial and error, experience, intuition, and, increasingly, formalised experimentation (to be discussed below (see also: Deville 2012a)); that said, in my experience it is common for collections agents to use these as a framework which they then adapt to their own style.

This collections company, for instance, specialises in seeking repayment in full, from debtors at a relatively early stage of default. This meant that, as in the above conversation, the company keeps pushing for a large payment, willing to wait some time, and potentially have a number of conversations with a debtor, before beginning to negotiate a lower or staggered repayment plan. A contrast would be a company operating with more established defaulters, where the creditor (whether the debtor knows it or not) effectively decides that the chance of a full repayment is slight, with the primary aim becoming instead to collect smaller ongoing repayments, of the kind Sarah mentions at the end of the call (this was the case in another of the agencies I visited). In both models, however, the aim — as Zsuzsanna Vargha (2011) illustrates in 
the analogous conversations that can accompany the selling credit—is to stabilise both the particular product's properties and the customer. In this case, Tom's aim is to solidify and intensify the attachments that bind Sarah to this particular product, and to individualise this debt in relation to the competition, by making it not just part of the undifferentiated 'debt' which combine to form part of the background of her life, but a product that resonates strongly in the present, needs to be acted on immediately - or, more precisely, at least by 5pm Wednesday, or otherwise face the possibility of litigation. As noted, although Sarah has no way of knowing for sure, it in fact unlikely that this litigation will, in fact, occur-and certainly proceedings will not commence so soon.

The centrality of affect management, of rhythms of threat and empathy - and their potential concomitants fear and relief - to this particular market domain can, however, only be fully grasped by also understanding two further basic components of contemporary consumer collections strategy (in the UK, as much as anywhere else): the first is that all major creditors will segment their customer base and apply different collections strategies to different groups of debtors. These strategies will be divergent within the collections operations of a particular creditor. It is now routine for larger creditors to develop these strategies according to scoring models, derived through forms of econometric analysis, the aim of which is to tailor collections strategies to particular groups of debtors, and to enable collectors to prioritise some debts over others. One potential outcome is to direct the creditor's collections operations at those debtors that will not only repay, but also repay more than others in an otherwise similar situation (see also Deville 2012). Another is to enable the creditor to better manage risk. In lending this centres on the analysis of the potential of default involving, amongst other indicators, a customer's credit score and account history. 
However, in the world of collections, where the debtor is already 'delinquent', as the industry terminology has it, this centres on an assessment creditor's potential losses if a debt, potentially already in default, proves non recoverable..$^{i i i}$

The idea is that "high risk accounts are accelerated automatically to a more intensive collections strategy, increasing the speed and likelihood of recovery" (Experian Decision Analytics 2006, 3). A more intensive collections strategy: what might this mean? Is there anything beyond mere terminological coincidence in the echo of analyses of affective intensity? In collections, intensity is partially shorthand for a cost calculation: 'more intensive' collections refers to a greater level of expenditure on recovering debt from some accounts rather than others. However, the term also captures the very material increase in the collections effort: a consequence of increased intensity is almost certainly more frequent attempts at contact, as well as potentially an increase in the modes of attempted contact (options include letter and phone). The particular mix will vary by collections organisation as well as by the segment being collected from, as summed up by this Barclays collections executive, speaking at a recent collections conference in the UK:

"you apply scoring models, every kind of models that you may have, you will [then] reach the workable accounts [i.e. those worth subjecting to collections processes], you will give [these] to the operations [department], you will decide how you are going to contact and when, and you decide the intensity.." (Coelho 2012)

How and when to contact and the intensity of contact are therefore variables that major consumer credit operations will almost certainly be working into their collections strategies. The results are major differences in the affective intersections between collector and debtor, along terms which individual debtors are likely to be wholly unaware. 
How are such strategies decided? Here it is important to understand the second central, commonplace component of contemporary collections strategy: the deployment of forms of in vivo experimentation (Çalışkan and Callon 2010, 19), what is referred to as 'champion versus challenger' testing. Experian explains the process as follows:

Perhaps the most important improvement an organisation can take is to regularly review its processes and continually evolve its approach to collections through experimentation. Champion v[ersus] challenger allows the organisation to test in a controlled manner the timing, approach, tone, message, and segmentation of the collection process on a small population of its debtor base in order to understand what works and what doesn't in different circumstances. Results in the test environment can be measured and compared against the dominant champion strategy. Successful evolutions can then be rolled out across the broader debt portfolio. (Experian 2009b, 19; emphasis added; see also: Experian Decision Analytics 2008; Deloitte 2009)

Experimentation can be applied to a range of variables, including method of contact, time of contact, timings between contact, the collections scripts used on the telephone by particular collections agents, and the particular mix of all these (and many more). A newly optimised 'challenger' sample is unleashed against a small sample of the debtors, with the aim of assessing its effectiveness against the existing 'champion'.

It is important to note that, even if its sophistication has improved markedly, the principle of champion challenger is not new. Rock noted as far back as 1973 that collections procedures were 'organized around a serial testing system' $(1973,92)$. In this light, given that the debtor has long been seen as a modifiable and testable entity, it is not surprising to find champion challenger's quantitative methodologies sitting quite comfortably alongside and in interaction with other more experiential and qualitative modes of knowledge on how to influence defaulting debtors, ranging from circulating industry knowledge about their likely responses to particular approaches, to more formalised use qualitative research methodologies. One of the managers at a 
collections agency where I was based, for example, described how their letters are circulated amongst key senior staff and minutely deconstructed before being sent out, with the language, the layout, all the potential subject of discussion. This is more or less the same method that was used in a focus group recently conducted by Experian, whose conclusions included the following:

'Customers need to be threatened with the consequences of not paying.'

'Scare-tactics without the possibility of working out a solution are likely to result in a "head in the sand mentality."

'Respondents expect a different approach and tone of voice depending on (a) the amount owed; (b) how overdue the debt is and (c) the type of company communicating to them.'

'Serious threats ([c]redit rating, legal action) tend to concern younger audience far more'

'Informal language is ineffective'

'The prospect of home visits works for late payers'

'The younger group favoured headlines in bold and red (since they were accustomed to waiting for 'red letters'). Older respondents were less influenced by red text. Respondents also suggested that using red to highlight more than one area of a letter is ineffective.'

(Experian 2009a, 24)

Whether these insights reflect the reality of experiencing debt collections letters is not the point here. What this survey stands for is the presence in the collections of routine debates about the precise layout of collections letters, mirroring similar debates about the content of phonecalls and the usefulness/effectiveness of other collections methods (email, SMS, doorstep collections, for instance - all common topics in industry conferences and publications). In this case what is noteworthy is the absence of debates about economic calculation: presenting the raw financial implications of debt and coaxing debtors into cost-benefit calculations about their particular debt may be one part of collections, but here this is by and large replaced by the analysis of how to generate moments of affective intensity, ranging from the use of colour, tone of voice, type of language used, the variable efficacy of specific 
threats, as well as — importantly_-the possibility of relief, here coded as the need to offer at least the promise of a solution.

How, then, might some of these diverse modes of affective address be combined as part of a comprehensive collections strategy targeted at a particular debtor and rolled out against him or her over time? This can be illustrated by following a collections letter sequence. More specifically, here I present some of the key stages through which an account might go through, when passing through a creditor's internal collections department, drawing on letters uploaded onto an online debt advice forum by debtors themselves. ${ }^{\text {iv }}$ This example centres on an account which begins life as a credit card account held by Halifax, a major UK financial services provider, that is already quite far into the process of going 'bad' (and owned by the Lloyds Banking Group). That is, the debtor is showing the creditor real signs that he or she is not willing or able to repay the full outstanding balance. With the account potentially heading towards default (defined usually within the industry as meaning three consecutive missed payments (CMRC 2008, 27)), it is passed to Halifax's internal 'Retail Bank Collections Team'. It should be noted that the choice of bank brand, has been made primarily on the basis of the availability of letter evidence. However similar processes are by no means restricted to Halifax, or indeed to the wider collections industry.

As shown in figure 1, the letters this team sends out progress from an early stage collections letter (Letter 1), to a default notice (Letter 2), to a final 'last chance' letter (Letter 3). Each of these letters mark or draw attention towards a significant passage point on the journey into default. These are enacted by the deployment of a sequence of 'disentanglement' or detachment devices (Callon, Méadel, and Rabeharisoa 2002), serving both practical and symbolic functions. The first of these is designed to prevent 
the borrower building up any more credit. The key attachment device that mediated the customer-lender relationship up to this point — the credit card-is rendered inoperable and 'cancelled'.

\section{Figure 1. Three internal collections letters}

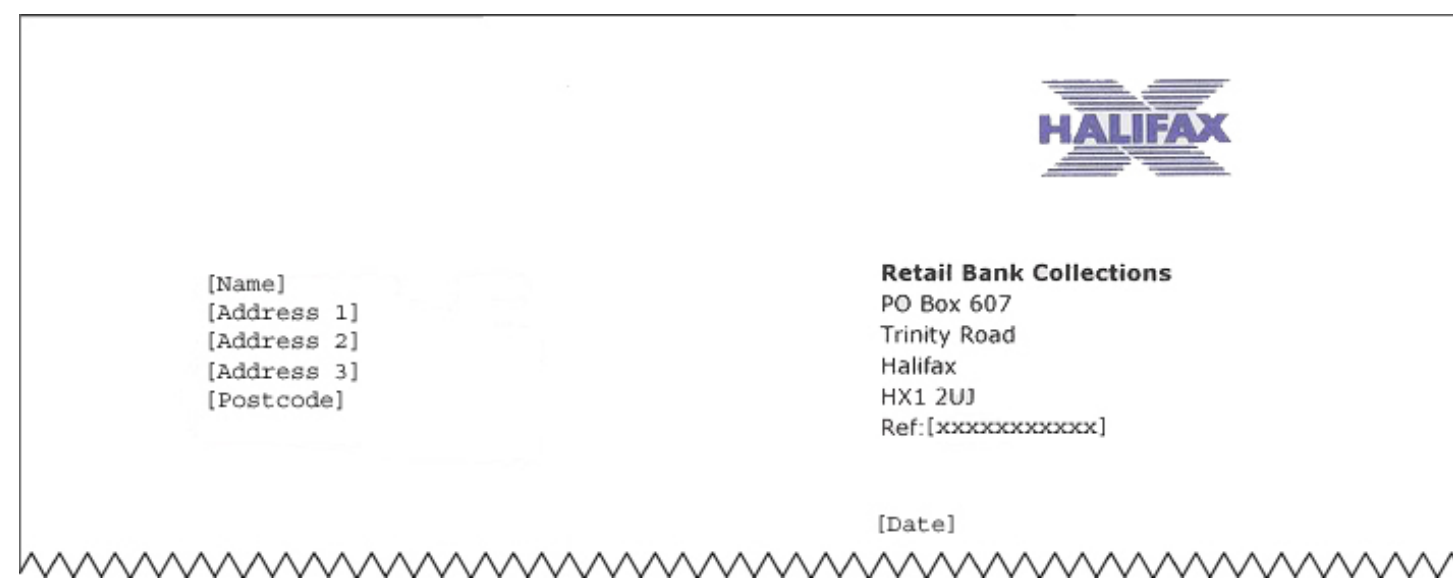

Letter 1: Early stage collections

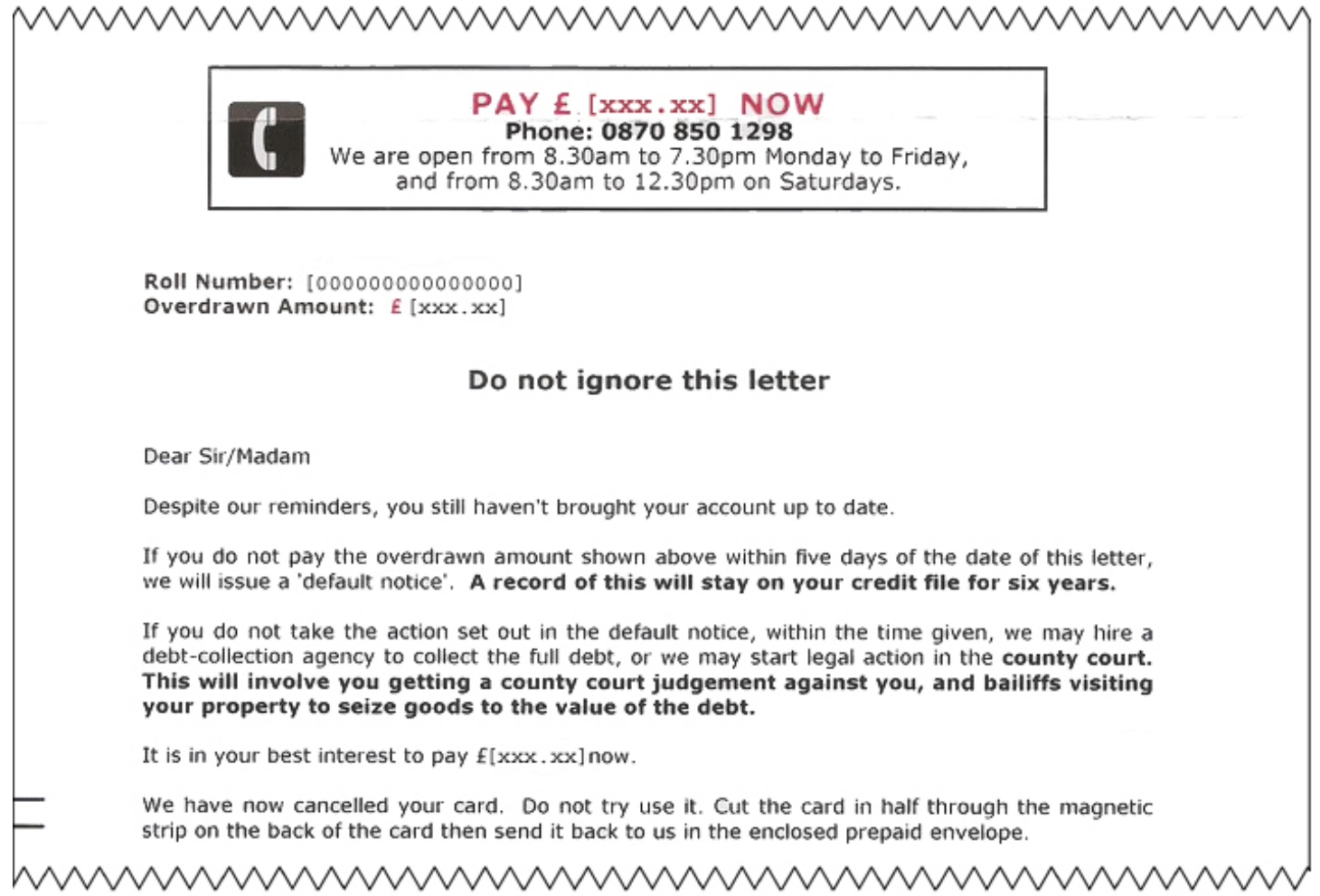

Letter 2: Default notice 


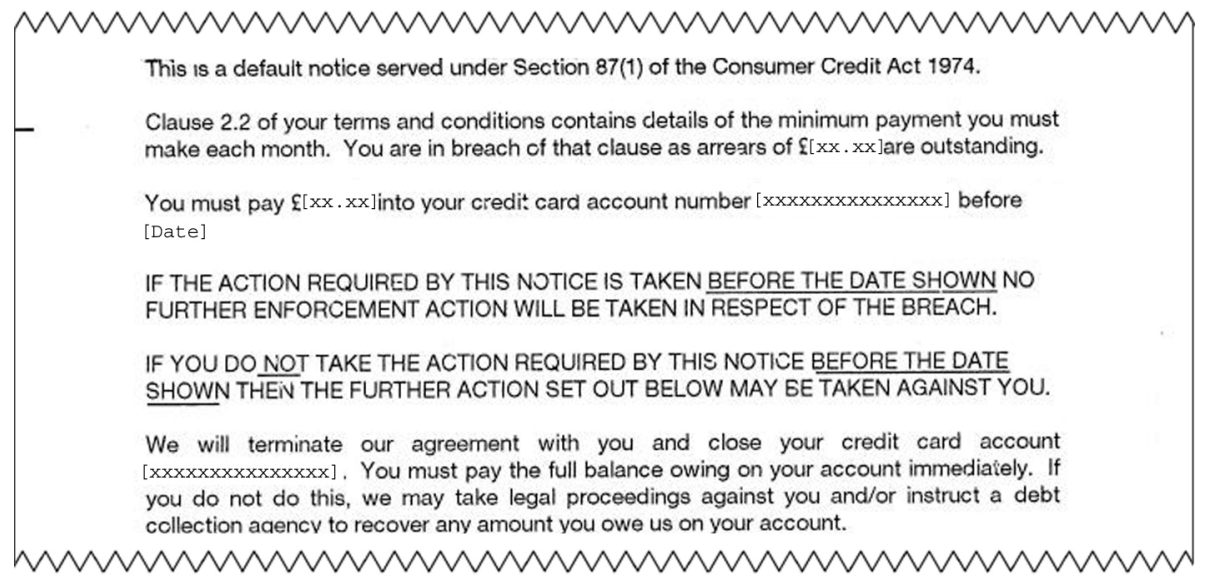

Letter 3: Last chance

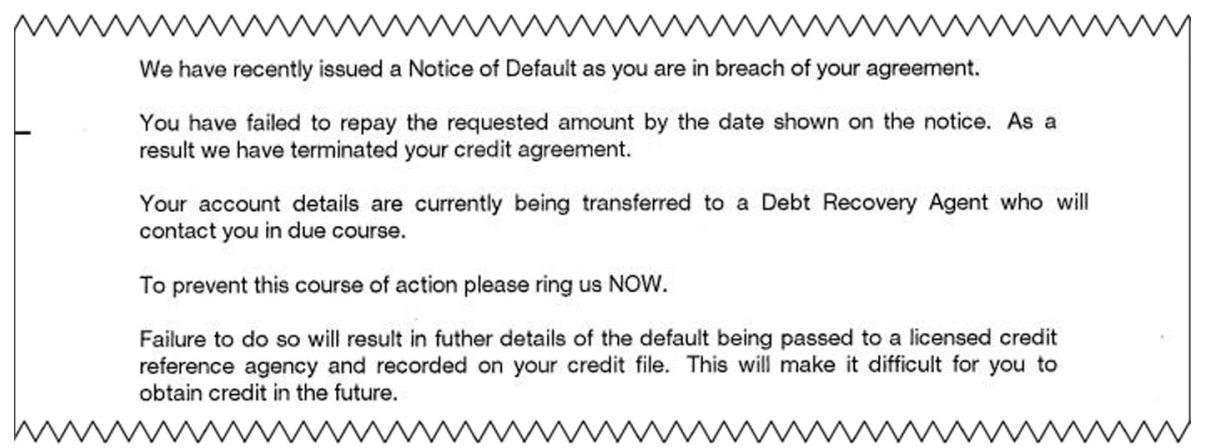

The second passage point is legal: the serving of a 'default notice'. An unsecured creditor will typically spend at least some time trying to collect on outstanding debts, however after between 3 and 6 months without payment having been received the borrower will be formally notified that a debt will go into 'default' (if repayment is not made within 28 days; for further details see Information Commissioners Office (2007)). This notification must be conveyed in written form before a creditor can take any action to recover all or part of a debt (which in accordance with amendments made in 2006, cannot commence until fourteen days after being issued (Department for Business Information and Skills 2006, 14.36). This letter is thus different from many associated with being subject to debt collection, in that the credibility of its threat is jointly accomplished by the collector and an external agent: the legal framework within which the creditor is bound. However, it also marks a secondary passage point for the debtor, as the creditor must report the default to the credit 
reference agencies. This is, from the debtor's point of view, perhaps more serious than having a card cancelled. For, while missed payments will only have a temporary impact on a borrower's credit rating if repayments resume, a default stays on a credit file for six years. Having even one default on a credit file may severely impact the possibility of obtaining future credit through conventional routes for this period-as Daniel, from a major UK credit reference agency, put it 'when you have defaults on your credit file, you are instantly sub-prime, basically'.

The final letter is less marking a passage point, as pointing towards one. It is framed as the last chance for the borrower to act, before the account is passed away from the creditor, towards a 'Debt Recovery Agent'. The message is clear: after this point, the debtor will have to deal with someone else.

It is important to recognise that in this journey from creditor towards collector, there are, to a greater extent than later in the collections cycle, genuine sanctions being threatened and enacted against the debtor. The debtor progressively loses their right to borrow from the creditor and, if they do not respond to Letter 3, their future right to other (non-sub-prime) credit. However, mixed in with these potential or actual sanctions are a range of other semiotic, often affectively oriented devices that seek to shape the calculative space of the debtor. Based on an examination of hundreds of letters, variations of most of these are extremely common in the collections industry. These include the deployment of explicit threats, including: ${ }^{\mathrm{v}}$

- Threatening legal action: from highlighting — sometimes in bold-various possible legal outcomes, including action being taken in a 'county court', 'bailiffs' and the particularly resonant promise of them 'visiting the property to seize goods to the value of the debt' (Letter 1), to the more nebulous threat of 'legal proceedings' (Letter 3).

- Threatening a debtor's credit file

The letters also employ varied modes of address, including: 
- Suggesting the borrower retains the (latent) capacity to self-govern: 'It is in your best interest...' (Letter 1); 'This will make it difficult for you to obtain credit in the future' (Letter 3); 'please' (Letter 3);...

- ... as compared to seeing debtors as responding best to didactic orders: 'Do not ignore this letter' (Letter 1); 'Do not try to use it' (Letter 1); 'You must pay...' (Letter 2).

Finally, the letters employ use a range of mechanisms to attempt to be intensive,

striking, and/or high impact, including:

- Strategically using colour, typographic and graphic design: Red to imply urgency (Letter 1); bold, centralised text (Letter 1); various other strategically HIGHLIGHTED SHOUTING throughout.

- Suggesting processes are being set in motion: the most resonant of these is in Letter 3, which speaks of 'Your account details [...] currently being transferred to a Debt Recovery Agent' (Letter 3, emphasis added). The letter evokes action that is being taken in the present, to the extent that the reader is asked to imagine what is depicted as the physical labour of transferring account details to a third party, at the very point at which the letter is being read.

- Seeking to elicit immediate action: these are omnipresent in collections letters; here, they include: 'To prevent this course of action please ring us NOW'; 'PAY $£[\mathrm{xxx} . \mathrm{xx}] \mathrm{NOW}$ ' (in red); 'If you do not pay within five days of the date of this letter'; and so forth.

- Using capitalisation and syntax to imply legal status: these include here a 'default notice' becoming a 'Notice of Default' between letters 2 and 3 and a 'debt collection agency' becoming a 'Debt Recovery Agent'.

These devices - ranging from the explicitly to the implicitly threatening, from attempts to elicit self governance, to attempts to impose a worldview on the debtor, to raising and lowering the affective intensity of the letter-can be seen as trying to successfully 'resonate' with the reader that picks it up. ${ }^{\text {vi }}$ That is to say, these letters should not be seen as operating in a vacuum: instead, they are affective 'lures', aimed at prompting calculative engagement by intersecting with both the readers' anxious anticipatory domestic landscapes and their emergent dispositional tendencies, with the latter including their very particular embodied history and expertise.

When grouped together, however, some of the weaknesses of the collector begin to seep through. What happens, for instance, to the very specific legal threats from Letters 1 to 3 ? A detailed range of consequences, becomes a nebulous 'legal action', 
before disappearing altogether. Meanwhile, although the threat of potential damage to the debtor's credit file is raised first in Letter 1, by Letter 3 the credit reference agency has still not been notified. In fact, the only threat that is carried out over the course of this sequence, is the serving of the default notice in Letter 2. The problem for the debtor is that unless the reader has the expertise to themselves do the work of reading against the collections letter, such weaknesses are likely to remain hidden. Instead they are left wondering as to a range of potential future outcomes: Will a bailiff be sent round? Is it in my best interest to repay rather than damage my credit rating? Do I need access to consumer credit in the next six years? Do debt collectors really take people like me to court? The result is the active intensification of indeterminacy which, the collector well knows, is one of the prerequisites for prompting the debtor into contacting them and, potentially, repaying (at least something).

\section{Conclusion}

I have argued that, in tracing market processes, there is room to expand both the vocabulary and empirical focus of both economic sociology and consumer studies, to render it capable of speaking to the centrality of the production and management of affect in and through markets. A consequence is that there is a need for methods and theoretical tools sensitive to such processes, able to trace the emergent and the inbetween.

Affect is not an analytical category equally relevant to all market spaces. There are plenty of ways in which market processes format a diverse range of spaces, including many spaces of consumption, so as to deliberately render the embodied, emergent qualities of life the unnoticed 'background' to routine socio-economic encounters. At the same time it should not be assumed that such processes are contained in the 
everyday, including the intimate spaces of the home. As I have argued, they are clearly present in the heart of the collections industry. Given both debtors' constrained financial means and the competition within the collections market, the collector's task is to focus calculative attention on them, not a competitor. Generating an ongoing state of future oriented 'anxious anticipation' is part of this. But, it is by 'capturing' these emergent, affective affordances that the collector hopes to achieve this calculative focus.

The paper has also sought to open up both consumption and mechanisms of market attachment as processes which are very different depending on from where and when they are being viewed and (re)made. This points to the shifting ontologies of market attachment. Attachments generated in prior moments of consumption take on very different identities when subsequently combined with other forms of borrowing in an aggregated outstanding balance that a debtor cannot repay. Market attachments are also very different for the debtor, who feels resolutely attached to their debts, and for the collector, for whom their debtors are all too loosely attached. For the debtor with multiple debts, this competition for their attachment is largely meaningless. They are attached to their debts as a whole; being more or less connected to one creditor over others will do little to resolve their overall position. ${ }^{\text {vii }}$ For the creditor meanwhile, the debtor's overall market attachment is only a peripheral concern. What matters most, is a debtor's attachment to them. In the case of consumption, meanwhile, the possibility of debtor detachment means that, for the collector at least, the debtor remains, long past the moment of initial borrowing, a 'debtor-customer' hybrid. As so often, the apparent peculiarities of default serve to illustrate the messy co-production of markets according to multiple interacting logics certainly not limited to those of the market. ${ }^{\text {vii }}$ In the world of collections, the success of such interactions depends on, and is 
amplified through, the targeted, experimentally shaped, affective inbetweens that

routinely connect defaulter with collector.

\section{Acknowledgements}

I would like to thank Paul Langley, Gregory Seigworth and the two anonymous

reviewers for their helpful comments on a draft of this paper. This research was

funded by the Economic and Social Research Council, award number PTA-031-2006-

00457.

Notes

\footnotetext{
i Drawing on data derived from the Consumer Credit Counselling Service's (recently renamed StepChange) analysis of their client base (CCCS, 2009, 2010, 2012).

${ }^{\text {ii }}$ For more information on the use and controversies surrounding the use of Charging Orders to achieve this, see Tutten (2009).

iii The measures of risk will vary by the business model of the creditor, as well as the regulatory regime they are working under. Under the current Basel II agreement, banks are required to provide assessments of three key indicators: Probability of Default (PD), Loss Given Default (LGD), Exposure at Default (EAD) (see: Deloitte (2006); Experian (2006))

iv The Consumer Action Group (http://www.consumeractiongroup.co.uk). The sequence of letters depicted in this paper has been reconstructed according to insights from a range of sources but cannot attempt the task of mirroring the changing trajectories that collectors will deploy over time, or in relation to different types of debtor.

'See Rock's (1973, 51-106) analysis of the in many way similar threats being deployed in the $1970 \mathrm{~s}$.

${ }^{\text {vi }}$ See Massumi's use of resonance/resonation as a metaphor for the inbetweenness of the relations through which entities operating at different scalar registers intersect and interact with one another. Specifically Massumi is referring intimate, corporeal forms of causality; as he puts it, resonation is the 'qualitative transformation of distance into an immediacy of self-relation' (Massumi 2002, 14). Also relevant is the analysis of the 'resonance machines' that have been argued to be characteristic of contemporary capitalism (Connolly 2005; drawing in part on Deleuze and Guattari 1988, 208-231).

vii One notable exception to this can occur when debtors seek to renegotiate their debts, perhaps assisted by a third party. Here the attempt is to convince all creditors to accept a reduced repayment amount. But one or more creditors may resist this. In these cases, individual company identities do, very much, come to matter.

viii On the need to contain and deny such 'monstrous' but inevitable hybridity, see Slater (2011) (thanks also to the anonymous reviewer who provided me with the reference).
}

\section{References}

Adams, Vicanne, Michelle Murphy, and Adele E. Clarke. 2009. Anticipation: Technoscience, life, affect, temporality. Subjectivity 28, no.1: 246-265.

Adkins, Lisa. 1995. Gendered work: Sexuality, family and the labour market. Buckingham; Bristol, PA: Open University Press. 
2005. The new economy, Property and personhood. Theory, Culture \& Society 22, no. 1: 111-130.

Adkins, Lisa, and Celia Lury. 1999. The labour of identity: Performing identities, performing economies. Economy and Society 28, no.4: 598-614.

Araujo, Luis, Hans Kjellberg, and Rob Spencer. 2008. Market practices and forms: Introduction to the special Issue. Marketing Theory 8, no.1: 5-14.

Arvidsson, Adam. 2002. On the "pre-history of the panoptic sort": Mobility in market research. Surveillance \& Society 1, no.4: 456-474. . 2005. Brands: A critical perspective. Journal of Consumer Culture 5 no. 2: 235-258.

Ayub, Ebrahim. 2004. Identifying the optimum collections strategy through the use of champion challenger Analytical Tools. http://www.gentrack.com/content//champchallwp.pdf.

Bar-Gill, Oren. 2006. Bundling and consumer misperception. The University of Chicago Law Review 73, no. 1: 33-61.

Baudrillard, Jean. 1998. Consumer society: Myths and structures. London: Sage.

Bauman, Zygmunt. 2007. Consuming life. Cambridge: Polity Press.

Beckett, Antony. 2011. Governing the consumer: Technologies of consumption. Consumption Markets \& Culture 15, no. 1: 1-18.

Beunza, Daniel, and Raghu Garud. 2007. Calculators, lemmings, or frame-makers? The intermediary role of securities analysts. In Market devices, ed. Michel Callon, Yuval Millo, and Fabian Muniesa, 13-39. Oxford: Blackwell.

Beunza, Daniel, and David Stark. 2004. Tools of the trade: The socio-technology of arbitrage in a Wall Street trading room. Industrial and Corporate Change 13, no. 2: 369-400.

Burton, Dawn. 2008. Credit and consumer society. London: Routledge.

Çalışkan, Koray, and Michel Callon. 2009. Economization, part 1: Shifting attention from the economy towards processes of economization. Economy and Society 38, no. 3: 369-398.

2010. Economization, part 2: A research programme for the study of markets. Economy and Society 39, no. 1: 1-32.

Callon, Michel. 1986a. The sociology of an Actor-network: The case of the electric vehicle. In Mapping the dynamics of science and technology: Sociology of science in the real world, ed. Michel Callon, John Law, and Arie Rip, 19-34. London: Macmillan Press.

. 1986b. Some elements of a sociology of translation: Domestication of the scallops and the fishermen of St. Brieuc Bay. In Power, action, and belief: A new sociology of knowledge?, ed. John Law, 196-233. London: Routledge \& Kegan Paul.

2002. Writing and (re)writing devices as tools for managing complexity. In Complexities: Social studies of knowledge practices, ed. John Law and Annemarie Mol, 191-217. Durham, N. Ca: Duke University Press. . 2005. Why virtualism paves the way to political impotence. Economic Sociology European Electronic Newsletter 6, no. 2: 3-20.

2007. What does it mean to say that economics is performative? In Do economists make markets: On the performativity of economics, ed. Donald MacKenzie, Fabian Muniesa, and Lucia Siu, 311-357. Princeton and Oxford: Oxford University Press.

. 2010. Performativity, misfires and politics. Journal of Cultural Economy 3, no. 2: $163-169$. 
Callon, Michel, Cecile Méadel, and Vololona Rabeharisoa. 2002. The economy of qualities. Economy and Society 31, no. 2: 194-217.

Clough, Patricia. T. 2009. The new empiricism: Affect and sociological method. European Journal of Social Theory 12, no. 1: 43-61.

Cochoy, Franck.. 2002. Une sociologie du packaging, ou l'âne de buridan face au marché. Paris: Presses Universitaires de France. 2007. A brief theory on the "captation" of publics: Understanding the market with little red riding hood. Theory, Culture \& Society 24, nos. 7-8: 203-223. . 2008. Calculation, qualculation, calqulation: Shopping cart arithmetic, equipped cognition and the clustered consumer'. Marketing Theory 8, no. 1: $15-44$.

2011. De la curiosité, l'art de la séduction marchande. Paris: Armand Colin. 2012. La sociologie economique relationniste. In Du lien marchand: Comment le marché fait société. Essai(s) de sociologie économique relationniste, ed. Franck Cochoy. Toulouse: Presses Universitaires du Mirail, 19-54.

Coelho, Sérgio. 2012. The use and selection of proper remedial tools: Maximisng your collections stage. Presented at CCR-interactive 2012, September 28, Guoman Tower Hotel, London. http://www.ccrinteractive.com/index.php?option=com_content\&task=view\&id=1386\&Itemid $=95$.

Connolly, William E. 2005. The evangelical-capitalist resonance machine. Political Theory 33, no. 6: 869-886.

Consumer Credit Counselling Service. 2009. CCCS statistical yearbook 2008. Consumer Credit Counselling Service.

http://www.cccs.co.uk/Portals/0/Documents/media/reports/statisticsyearbooks/ stats-yearbook-2008.pdf.

. 2010. CCCS statistical yearbook 2009. Consumer Credit Counselling Service.

http://www.cccs.co.uk/Portals/0/Documents/media/reports/statisticsyearbooks/ stats-yearbook-2009.pdf.

. 2012. CCCS statistical yearbook 2011. Consumer Credit Counselling

Service.

http://www.cccs.co.uk/Portals/0/Documents/media/reports/statisticsyearbooks/ stats-yearbook-2011.pdf.

Cook, Nicole, Susan J. Smith, and Beverley A. Searle. 2009. Mortgage markets and cultures of consumption. Consumption Markets \& Culture 12, no. 2: 133-154.

Cooren, François. 2004. Textual agency: How texts do things in organizational settings. Organization 11, no. 3: 373-393.

Cooren, François, Boris H. J. M. Brummans, and Damien Charrieras. 2008. The coproduction of organizational presence: A study of Médecins Sans Frontières in action. Human Relations 61, no. 10: 1339-1370.

Credit Management Research Centre. 2008. Credit and debt management survey 2008. Leeds University Business School. http://www.cmrc.co.uk/wpcontent/uploads/CreditandDebtSurvey2008.pdf.

Credit Services Association. 2012a. Credit Services Association: Code of practice. http://www.csauk.com/media/editor/file/CSA\%20Code\%20of\%20Practice\%281\%29.pdf 
2012b. CSA revises code in advance of new regulatory regime.

http://www.csa-uk.com/csa-news/73/csa-revises-code-in-advance-of-newregulatory-regime.

Danna, Anthony 2002. All that glitters is not gold: Digging beneath the surface of data mining. Journal of Business Ethics 40, no. 4: 373-386.

Deleuze, Giles, and Felix Guattari. 1988. A thousand plateaus: Capitalism and schizophrenia. London: Athlone Press.

Deloitte. 2009. Achieving excellence in default management. http://www.deloitte.com/assets/Dcom-

UnitedStates/Local\%20Assets/Documents/us_fsi_BS_Default\%20managemen t_sept08.pdf.

Department for Business Information and Skills. 2006. Amendments to Consumer Credit Act. http://www.opsi.gov.uk/acts/acts2006/en/06en14-a.htm.

Deville, Joe. 2010. The landscape of consumer credit default: Tracing technologies of market attachment. Unpublished PhD Thesis. London: Goldsmiths, University of London.

2012a. Regenerating market attachments: Consumer credit debt collection and the capture of affect. Journal of Cultural Economy 5, no. 4.

. 2012b. Sélection et "collection": Le recouvrement et la régénération des attachements marchands. In Du lien marchand: Comment le marché fait société. Essai(s) de sociologie économique relationniste, ed. F. Cochoy. Toulouse: Presses Universitaires du Mirail, 273-294.

Deloitte. 2006. Unleashing the power: Driving profits through risk-based collections. http://www.deloitte.com/assets/DcomIreland/Local\%20Assets/Documents/ie_FS_UnleashingthePower_1008.pdf.

Dowling, Emma. 2012. The waitress: On affect, method and (re)presentation. Cultural Studies $\leftrightarrow$ Critical Methodologies 12, no. 2: 109-117.

Dowling, Emma, R. Nunes, and B. Trott. 2007. Immaterial and affective labour: Explored. Ephemera: Theory in Politics \& Organization 7, no. 1: 1-7.

Engelen, Ewald. 2008. The case for financialization. Competition and Change 12, no. 2: $111-119$.

Experian. 2009a. The impact of the effective use of tone of voice in collection letters. http://www.experian-da.com/resources/instant/articles/AICM_July_2009_p2224.pdf.

2009b. Experian collections landscape report: An Experian white paper. Nottingham: Experian.

Experian Decision Analytics. 2006. Improving Basel II credit risk ratings. Decision Analytics briefing paper. http://www.experian.co.uk/assets/decisionanalytics/briefing-papers-global/ExperianDA BP Basel.pdf. . 2008. Identifying the Optimum Collections Strategy Through the Use of Champion Challenger Analytical Tools. Decision Analytics Briefing Paper. http://www.experian.ie/assets/decision-analytics/whitepapers/experian_champion_challenger.pdf.

Finch, John, and Susi Geiger. 2011. Constructing and contesting markets through the market object. Industrial Marketing Management 40, no. 6: 899-906.

French, Shaun, Andrew Leyshon, and Thomas Wainwright. 2011. Financializing space, spacing financialization. Progress in Human Geography 35, , no. 6: 798-819.

Gandy, Oscar H. 1993. The panoptic sort: A political economy of personal information. Boulder, CO: Westview Press. 
Gomart, Emilie, and Antoine Hennion. 1999. A sociology of attachment: Music amateurs, drug users. In Actor network theory and after, 220-247. Oxford: Blackwell.

Granovetter, Mark 1985. Economic action and social structure: The problem of embeddedness. American Journal of Sociology 91, no. 3: 481-510.

Grossberg, Lawrence. 2010. Affect's future: Rediscovering the virtual in the actual. In The affect theory reader, ed. Melissa Gregg and Gregory J. Seigworth, 309338. North Carolina: Duke University Press.

Haraway, Donna. 1997.Modest_witness@second_millennium.FemaleMan@_meets_ OncoMouse: Feminism and technoscience. New York and London: Routledge.

Hardie, Ian, and Donald MacKenzie. 2007. Assembling an economic actor: The agencement of a hedge fund. The Sociological Review 55, no. 1: 57-80.

Hennion, Antoine. 2007. Those things that hold us together: Taste and sociology. Cultural Sociology 1, no. 1: 97-114.

Information Commissioners Office. 2007. Data protection technical guidance: Filing defaults with credit reference agencies.

http://www.ico.gov.uk/upload/documents/library/data_protection/detailed_spe cialist_guides/default_tgn_version_v3\%20\%20doc.pdf.

Kirton, Tony. 2010. Meaning business: The need for litigation. Credit Collections and Risk January: 25.

Klein, Lloyd. 1999. It's in the cards: Consumer credit and the American experience. Westport, Conn.: Praeger.

Knorr Cetina, Karen and Urs Bruegger. 2000. The market as an object of attachment: Exploring postsocial relations in financial markets. Canadian Journal of Sociology/Cahiers Canadiens De Sociologie 25, no. 2: 141-168.

Knox, Hannah, Damian O'Doherty, Theo Vurdubakis, and Chris Westrup. 2010. The devil and customer relationship management: Informational capitalism and the performativity of the Sign. Journal of Cultural Economy 3, no. 3: 339-359.

Langley, Paul. 2008a. The everyday life of global finance: Saving and borrowing in America. Oxford: Oxford University Press. 2008b. Financialization and the consumer credit boom. Competition and Change 12, no .2: 133-147.

Latour, Bruno. 1987. Science in action: How to follow scientists and engineers through society. Cambridge, MA: Harvard University Press. . 1999. Pandora's hope: Essays on the reality of science studies. Cambridge, Mass.: Harvard Univ Press. 2004. How to talk about the body? The normative dimension of science studies. Body \& Society 10, nos. 2-3: 205 -229.

Lazzarato, Maurizio. 1996. Immaterial labor. In Radical thought in Italy: A potential politics, ed. Paolo Virno and Michael Hardt, trans. Paul Colilli and Ed Emery, 133-147.

Lenglet, Marc. 2011. Conflicting codes and codings: How algorithmic trading is reshaping financial regulation. Theory, Culture \& Society 28, no. 6: 44-66.

Lépinay, Vincent. A. 2011. Codes of finance: Engineering derivatives in a global bank. Princeton, N.J.: Princeton University Press.

Leyshon, Andrew, and Nigel Thrift. 1999. Lists come alive: Electronic systems of knowledge and the rise of credit-scoring in retail banking. Economy and Society 28, no. 3: 434-466.

Lury, Celia. 2004. Brands: The logos of the global economy. London: Routledge. . 2009. Brand as assemblage. Journal of Cultural Economy 2, no. 1: 67-82. 
Lyon, David. 2001. Surveillance society: Monitoring everyday life. Buckingham and Phildelphia, PA: Open University.

MacKenzie, Donald. 2006. An engine, not a camera: How financial models shape markets. Cambridge, Mass.: MIT Press. 2009. Material markets: How economic agents are constructed. Oxford; New York: Oxford University Press.

Manning, Robert. 2000. Credit card nation: The consequences of America's addiction to credit. New York: Basic Books.

Marron, Donncha. 2009. Consumer credit in the United States: A sociological perspective from the 19th century to the present. New York: Palgrave.

Martin, Randy. 2002. Financialisation of daily life. Philadelphia: Temple University Press.

Massumi, Brian. 2002. Parables for the virtual: Movement, affect, sensation. Durham, NC and London: Duke University Press. 2005. Fear (the spectrum said). Positions: East Asia Cultures Critique 13, no. 1: $31-48$.

McFall, Liz. 2009. The agencement of industrial branch life assurance. Journal of Cultural Economy 2, no. 1: 49-65.

. (in press). Devising consumption: Cultural economies of insurance, credit and spending. London: Routledge.

Michael, Mike. 2006. Technoscience and everyday life: The complex simplicities of the mundane. Maidenhead: Open University Press.

Millo, Yuval. 2007. Making things deliverable: The origins of index-based derivatives. The Sociological Review 55, no. 2: 196-214.

Mol, Annemarie. 2002. The body multiple: Ontology in medical practice. Durham, N.C. and London: Duke University Press. . 2008. The logic of care: Health and the problem of patient choice. London and New York: Routledge.

Montgomerie, Johnna. 2006. The financialization of the American credit card industry. Competition and Change 10, no. 3: 301-319. . 2007. The logic of neo-liberalism and the political economy of consumer debt-led growth. In Neo-liberalism, state power and global governance, ed. Simon Lee and Stephen McBride, 157-172. Dordrecht: Springer. . 2008. Bridging the critical divide: Global finance, financialisation and contemporary capitalism. Contemporary Politics 14, no. 3: 233-252.

-2009. The pursuit of (past) happiness? Middle-class indebtedness and American financialisation. New Political Economy 14, no. 1: 1-24.

Munro, Moira. and Susan J. Smith. 2008. Calculated affection? Charting the complex economy of home purchase. Housing Studies 23, no. 2: 349-367.

Muniesa, Fabian. 2008. Trading-room telephones and the identification of counterparts. In Living in a material world: Economic sociology meets Science and Technology Studies, ed. Trevor J. Pinch and Richard Swedberg, 291-313. Cambridge, Mass. and London: The MIT Press.

Negri, Antonio. 1999. Value and affect. Boundary 2 26, no. 2: 77-88.

Office of Fair Trading. 2010. Consumers warned on "unenforceable debt" claims. http://www.oft.gov.uk/news-and-updates/press/2010/105-10. 2012. Debt collection: OFT guidance for businesses engaged in the recovery of consumer credit debts.

http://www.oft.gov.uk/shared_oft/consultations/OFT664Rev_Debt_collection g1.pdf. 
Poon, Martha. 2007. Scorecards as devices for consumer credit: The case of Fair, Isaac \& Company Incorporated'. In Market devices, ed. Michel Callon, Yuval Millo, and Fabian Muniesa, 284-306. Oxford: Blackwell. 2009. From new deal institutions to capital markets: Commercial consumer risk scores and the making of subprime mortgage finance. Accounting, Organizations and Society 34: 654-674.

Probyn, Elspeth. 2010. Writing shame. In The affect theory reader, ed. Melissa Gregg and Gregory J. Seigworth, 70-90. North Carolina: Duke University Press.

Ritzer, George. 2005. Enchanting a disenchanted world: Revolutionizing the means of consumption. Newbury Park, CA: Pine Forge Press.

Rock, Paul. 1973. Making people pay. London: Routledge \& Kegan Paul.

Seigworth, Gregory. J., and Melisa Gregg. 2010. An inventory of shimmers. In The affect theory reader, ed. Melissa Gregg and Gregory J. Seigworth, 1-25. North Carolina: Duke University Press.

Shaoul, Michael. 1997. The acrobat of desire: Consumer credit and its linkages to modern consumerism. London: Macmillan.

Shove, Elizabeth, and Luis Araujo. 2010. Consumption, materiality, and markets. In Reconnecting marketing to markets, ed. Luis Araujo, John Finch, and Hans Kjellberg, 13-28. Oxford; New York: Oxford University Press.

Slater, Don/ 2011. Marketing as monstrosity: The impossible place between culture and economy. In Inside marketing: Practices, ideologies, devices, ed. D. Zwick and J. Cayla, 23-41. Oxford; New York: Oxford University Press.

Stark, David. 2009. The sense of dissonance: Accounts of worth in economic life. Princeton, NJ: Princeton University Press.

Stran, Gary. 2008. A different view. Credit Management September: 29.

Thrift, Nigel. 2005. Knowing capitalism. London: Sage Publications. . 2007. Non-representational theory: Space, politics, affect. London: Routledge.

Tutton, Peter. 2009. Out of Order: CAB Evidence on the Use of Charging Orders and Orders for Sale in Debt Collection. London: Citizens Advice.

Vargha, Zsuzsanna. 2011. From long-term savings to instant mortgages: Financial demonstration and the role of interaction in markets. Organization 18, no. 2: $215-235$.

Wainwright, Thomas. 2009. The geographies of securitisation and credit scoring. PhD diss.. University of Nottingham. 2011. Elite knowledges: Framing risk and the geographies of credit. Environment and Planning A 43, no. 3: 650 - 665.

Zelizer, Viviana. 2001. The purchase of intimacy. Princeton and Oxford: Princeton University Press. . 2002a. Intimate transactions. In The new economic sociology: Developments in an emerging field, ed. Mauro F. Guillén, Randall Collins, Paula England, and Marshall Meyer, 274-300. New York: Russell Sage Foundation Publications. 2002b. Enter culture. In The new economic sociology: Developments in an emerging field, ed. Mauro F. Guillén, Randall Collins, Paula England, and Marshall Meyer, 101-125. New York: Russell Sage Foundation Publications.

Zwick, Detlev, Samuel K. Bonsu, and Aron Darmody. 2008. Putting consumers to work 'co-creation' and new marketing govern-mentality. Journal of Consumer Culture 8, no. 2: 163-196. 
Zwick, Detlev, and Janice Denegri Knott. 2009. Manufacturing customers: The database as new means of production. Journal of Consumer Culture 9, no. 2: $221-247$.

Zwick, Detlev, and Nikhilesh Dholakia. 2006. The epistemic consumption object and postsocial consumption: Expanding consumer-object theory in consumer research. Consumption, Markets \& Culture 9, no. 1: 17-43. 